\title{
The last glacial-interglacial cycle in Lake Ohrid (Macedonia/Albania): testing diatom response to climate
}

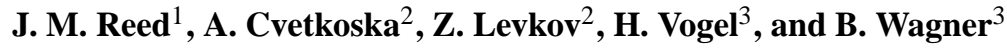 \\ ${ }^{1}$ Department of Geography, University of Hull, Cottingham Rd., Hull HU6 7RX, UK \\ ${ }^{2}$ Institute of Biology, Faculty of Natural Sciences, Gazi Baba bb, 1000 Skopje, Republic of Macedonia \\ ${ }^{3}$ University of Cologne, Institute of Geology and Mineralogy, 50674 Cologne, Germany
}

Received: 14 May 2010 - Published in Biogeosciences Discuss.: 17 June 2010

Revised: 15 September 2010 - Accepted: 21 September 2010 - Published: 13 October 2010

\begin{abstract}
Lake Ohrid is a site of global importance for palaeoclimate research. This study presents results of diatom analysis of a ca. $136 \mathrm{ka}$ sequence, Co1202, from the northeast of the lake basin. It offers the opportunity to test diatom response across two glacial-interglacial transitions and within the Last Glacial, while setting up taxonomic protocols for future research. The results are outstanding in demonstrating the sensitivity of diatoms to climate change, providing proxy evidence for temperature change marked by glacialinterglacial shifts between the dominant planktonic taxa, $C y$ clotella fottii and C. ocellata, and exact correlation with geochemical proxies to mark the start of the Last Interglacial at ca. $130 \mathrm{ka}$. Importantly, diatoms show much stronger evidence in this site for warming during MIS3 than recorded in other productivity-related proxies, peaking at ca. $39 \mathrm{ka}$, prior to the extreme conditions of the Last Glacial maximum. In the light of the observed patterns, and from the results of analysis of early Holocene sediments from a second core, Lz1120, the lack of a response to Late Glacial and early Holocene warming from ca. 14.7-6.9 ka suggests the Co1202 sequence may be compromised during this phase. After ca. $7.4 \mathrm{ka}$, there is evidence for enhanced nutrient enrichment compared to the Last Interglacial, followed by a post-Medieval loss of diversity which is consistent with cooling, but not definitive. Taxonomically, morphological variability in C. fottii shows no clear trends linked to climate, but an intriguing change in central area morphology occurs after ca. $48.7 \mathrm{ka}$, coincident with a tephra layer. In contrast, C. ocellata shows morphological variation in the number of ocelli between interglacials, suggesting climatically-forced
\end{abstract}

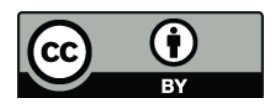

Correspondence to: J. M. Reed (j.m.reed@hull.ac.uk) variation or evolutionary selection pressure. The application of a simple dissolution index does not track preservation quality very effectively, underlining the importance of diatom accumulation data in future studies.

\section{Introduction}

Ancient Lake Ohrid is a site of global importance for longterm palaeoclimate reconstruction, with its long sediment record and key geographic location between the Mediterranean and Western Europe (Wagner et al., 2008). Its value also extends to testing hypotheses concerning biodiversity and the evolution of endemism in ancient lakes (Albrecht and Wilke, 2008).

Elsewhere, Lake Baikal, Siberia, is the prime example of an ancient graben in which extensive limnological and palaeolimnological research has demonstrated that diatoms (single-celled siliceous protists, commonly referred to as "algae") are the most important palaeolimnological palaeoclimate proxy (Mackay, 2007). Mackay (2007) notes that although diatoms tend to be absent during glacial phases, they are the most consistently preserved biological proxy for limnological reconstruction. In concert with modern limnology, palaeolimnological analysis of diatom data has been of fundamental importance in allowing competing hypotheses to be tested concerning the limnological response to climate change in this complex system.

Previously, Quaternary research in the circumMediterranean has had a strong bias towards vegetation change and/or quantitative pollen-based modelling of temperature and precipitation (e.g. Allen, 1999; GonzálezSampériz et al., 2005), sometimes combined with physical evidence for shoreline displacement and lake-level change

Published by Copernicus Publications on behalf of the European Geosciences Union. 
(Digerfeldt et al., 2000). Research on glacial-interglacial climate change in tectonic and volcanic lakes with relatively long sediment records has demonstrated that, while vegetation change appears to track glacial-interglacial climate change closely (e.g. Tzedakis et al., 2004; Allen and Huntley, 2009), the response is not linear, and uncertainty in regard to factors such as time lags in response hampers understanding of abrupt events in particular (Tzedakis, 2005, 2007).

The geographic influence of abrupt North Atlantic climatic events across terrestrial environments of southern Europe and the Mediterranean during the last glacial-interglacial cycle is still uncertain (Wohlfarth et al., 2008; Wagner et al., 2010). It is only surprisingly recently that the potential of diatoms has been exploited to test hypotheses of climate change in this topographically and climatically diverse region. Diatom response to glacial-interglacial climate change has been demonstrated clearly for Italian crater lakes (Ryves et al., 1996) and for montane regions of southern France (Rioual et al., 2007). In Lake Ioannina, NW Greece (Wilson et al., 2008), diatom shifts across the last glacial-interglacial transition provided the first convincing evidence for the impact in NW Greece of a Younger Dryas type abrupt reversal to cold, arid conditions during late glacial warming, in a relatively humid location where vegetation response was subdued (Lawson et al., 2004). During the Last Glacial period, diatom-inferred fluctuations in lake level and productivity during marine isotope stage MIS3-MIS2 in Les Echets, southeast France (Ampel et al., 2008; Wohlfarth et al., 2008) correlated closely with the climatic oscillations between Heinrich events and warmer Dansgaard-Oeschger interstadials which are strongly evident in the North Atlantic (e.g. Broecker, 2002) and Western Mediterranean (Cacho et al., 1999) marine record, and are arguably of hemispheric extent (e.g. Tierney et al., 2008 for Lake Tanganyika).

In comparison with most other ancient lakes, palaeolimnological research is in its infancy in Lake Ohrid. In advance of an International Continental Scientific Deep Drilling Project (ICDP), this study tests the response of diatoms to relatively well understood, major climate events during MIS6 (the penultimate glacial) to MIS1 (the Holocene). Core Co1202 is a well-dated sequence for which geochemical data are already published (Vogel et al., 2010a, b). Unlike the previous study of the last ca. $40 \mathrm{ka}$ preserved in core Lz1120 from the south of the basin (Wagner et al., 2009), which had a hiatus from 14.6 to $9.4 \mathrm{cal}$. ka BP, and a pioneering low resolution study of a core to the north of the basin by Roelofs and Kilham (1983), this new record offers the potential to test response to major events across two glacial-interglacial transitions and during the Last Glacial, within the temporal limits of analytical resolution adopted here. In the spirit of setting up protocols for future international collaboration, we also focus on taxonomic harmonization, while exploring morphological response at a sub-species level in the dominant planktonic taxa.
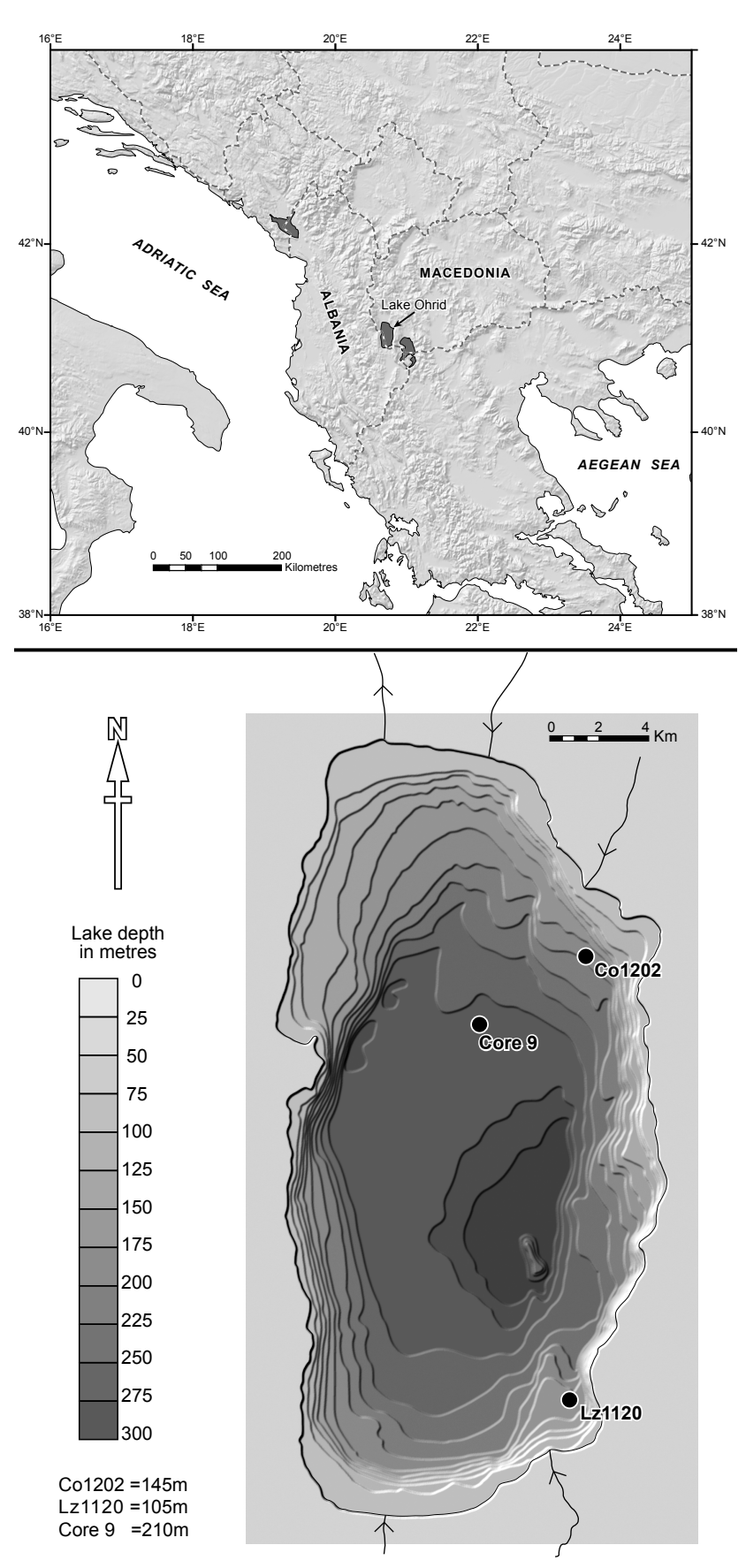

Fig. 1. Map showing the location of Ohrid on the border of Macedonia/Albania (inset) and the location of coring sites Co1202 (this study), Lz1120 (Wagner et al., 2009) and Co9 (Roelofs and Kilham, 1983), showing the direction of river flow. Modified from Albrecht and Wilke (2008) and Vogel et al. (2010b).

\section{The study site}

Lake Ohrid straddles the border of Macedonia and Albania in southern Europe $\left(41^{\circ} 01^{\prime} \mathrm{N}\right.$; $20^{\circ} 43^{\prime} \mathrm{E}$; Fig. 1) and is located at $693 \mathrm{~m}$ a.s.l. in the karstic mountainous region which 
extends in a continuous belt from the Dinaric Alps of Bosnia and Montenegro to the northeast, to the Pindus Mountains of Greece to the south. The lake has a surface area of $358 \mathrm{~km}^{2}$ and maximum depth of $289 \mathrm{~m}$. This is relatively small compared to other ancient graben lakes such as Baikal, Malawi or Tanganyika, so it has the potential advantage that it does not span several climate zones. The Mediterranean climate is more continental than the nearby Adriatic coastline; mean annual rainfall is $800-900 \mathrm{~mm}$, maximum temperature less than $31.5^{\circ} \mathrm{C}$ and minimum temperature above $-5.7^{\circ} \mathrm{C}$; Vogel et al. (2010b). Its open karst geology is an important influence both on the hydrology and nutrient budget of the lake; $55 \%$ of the inflow is from subterranean springs, and more than half of this volume is derived from a large aquifer which links Ohrid to Lake Prespa, located at a higher altitude $10 \mathrm{~km}$ to the east (Matzinger et al., 2006).

Lake Ohrid is oligotrophic and phosphorus limited (Allen and Ocevski, 1977). Historically, soluble reactive phosphorus did not exceed $4 \mu \mathrm{g} 1^{-1}$ in the period 1936-1939; nitrate levels were higher, often reaching $20 \mu \mathrm{g}^{-1}$ in the hypolimnion and $1-5 \mu \mathrm{gl}^{-1}$ in the epilimnion (Allen and Ocevski, 1977). The lake is still highly oligotrophic, with a Secchi disc depth of $14 \mathrm{~m}$ (Matzinger et al., 2006), but mean total phosphorus concentration has risen to $4.5 \mathrm{mg}-\mathrm{P} \mathrm{m}^{-3}$, exceeding its former predominantly ultra-oligotrophic state based on a classification boundary of $2.5 \mathrm{mg}-\mathrm{P} \mathrm{m}^{-3}$ (OECD, 1982). The most recently reported statistics for silica give a range of $<0.1$ to $2.6 \mathrm{mg} \mathrm{l}^{-1}$, almost reducing to zero in the epilimnion from mid-February to June (Stankovic, 1960). There are concerns that eutrophication may occur due to global warming and local anthropogenic impact (Matzinger et al., 2006, 2007) or is already evident (Matter et al., 2010).

\section{Methods}

The core Co1202 was collected from 145 m water depth in a coring location to the northeast of the lake (Fig. 1) using UWITEC piston and gravity coring equipment (www. uwitec.at; Vogel et al., 2010a); core sections were stored in the Cologne laboratory at $4{ }^{\circ} \mathrm{C}$. After correlation of individual core sections from which to construct a $14.89 \mathrm{~m}$ composite master sequence, firm chronological control was achieved through a combination of radiocarbon dating and tephrochronology. The chronology adopted here is that of Vogel et al. (2010a; see also Sulpizio et al., 2010), derived from linear interpolation between tie lines (Fig. 2). The sequence investigated here $(1489-17 \mathrm{~cm}$ depth) extends from ca. $135 \mathrm{ka}$ to $280 \mathrm{yrs}$ BP. A $16 \mathrm{ka}$ hiatus has been identified within, between 97.6 and $81.7 \mathrm{ka}$, occurring between subsamples at $1098.4 \mathrm{~cm}$ and $1052.1 \mathrm{~cm}$ depth in this study.

For diatom analysis, ca. $1 \mathrm{~cm}^{3}$ subsamples were taken every ca. $24 \mathrm{~cm}$ (ca. 600 a to $>3 \mathrm{ka}$ resolution), placed in sealed rigid sterile plastic containers and shipped to Hull, UK. Half the sediment was subsampled again into small Sterilin tubes

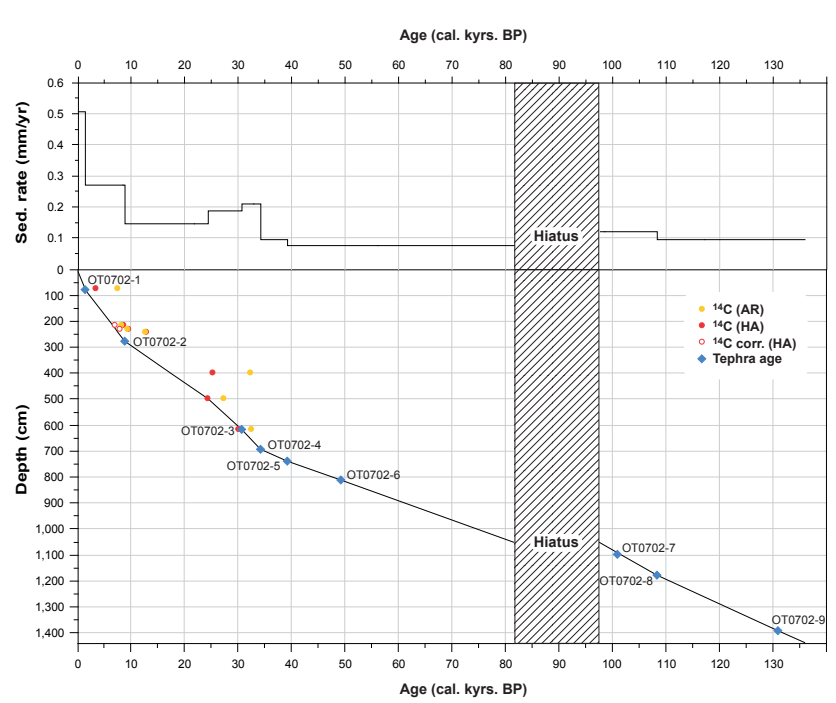

Fig. 2. Age-depth model for Co1202, showing estimated sediment accumulation rates. Radiocarbon ages were derived from alkaline residue (AR) and humic acid (HA) fractions of bulk sediment. Open circles denote corrected HA ages. Tephra age includes tephra and cryptotephra. See Vogel et al. (2010a) for more detail. (Modified from Vogel et al., 2010a).

and shipped to Skopje, Macedonia, being refrigerated again thereafter. In a preliminary study, the influence of different slide preparation techniques was investigated by eye in Skopje, and deemed to have little influence on preservation. In the UK, slides were therefore prepared using standard techniques (Battarbee, 1986), using hot $30 \% \mathrm{H}_{2} \mathrm{O}_{2}$ to oxidize organics, and a few drops of conc. $\mathrm{HCl}$ to remove carbonates; slides in Macedonia were prepared using cold $\mathrm{H}_{2} \mathrm{O}_{2}$, left overnight, prior to treatment with $\mathrm{HCl}$ and heating in a water bath for $30 \mathrm{~min}$, with centrifuging between stages. Microscope slides were prepared using Naphrax ${ }^{\mathrm{TM}}$ as a mountant. To allow parallel counting of the full sequence, around 350 rather than 500 valves per slide were counted where preservation was sufficient; although 500 is recommended (Battarbee, 1986), 350 should give good representativity in low-diversity assemblages such as in Lake Ohrid. Diatoms were counted under oil immersion at $\times 1000$ magnification on a Zeiss Axioscop 2 Plus in the UK and at $\times 1500$ magnification on a Nikon Eclipse 80i in Macedonia. They were identified using standard texts (Krammer and LangeBertalot, 1996, 1998, 1991a, b, 2000), and the dedicated Ohrid works of Hustedt (1945) and Levkov et al. (2007). A standard transect-based approach to counting (Battarbee, 1986) was adopted. Images were produced using a Nikon Coolpix 6000.

Ohrid's diatom flora is dominated during the Late Quaternary by two planktonic centrics, the endemic Cyclotella fottii Hustedt (syn. C. hustedtii) and the cosmopolitan C. ocellata Pantocsek (Fig. 3). Following recent modern taxonomic (Levkov et al., 2007) and palaeolimnological study (Wagner 


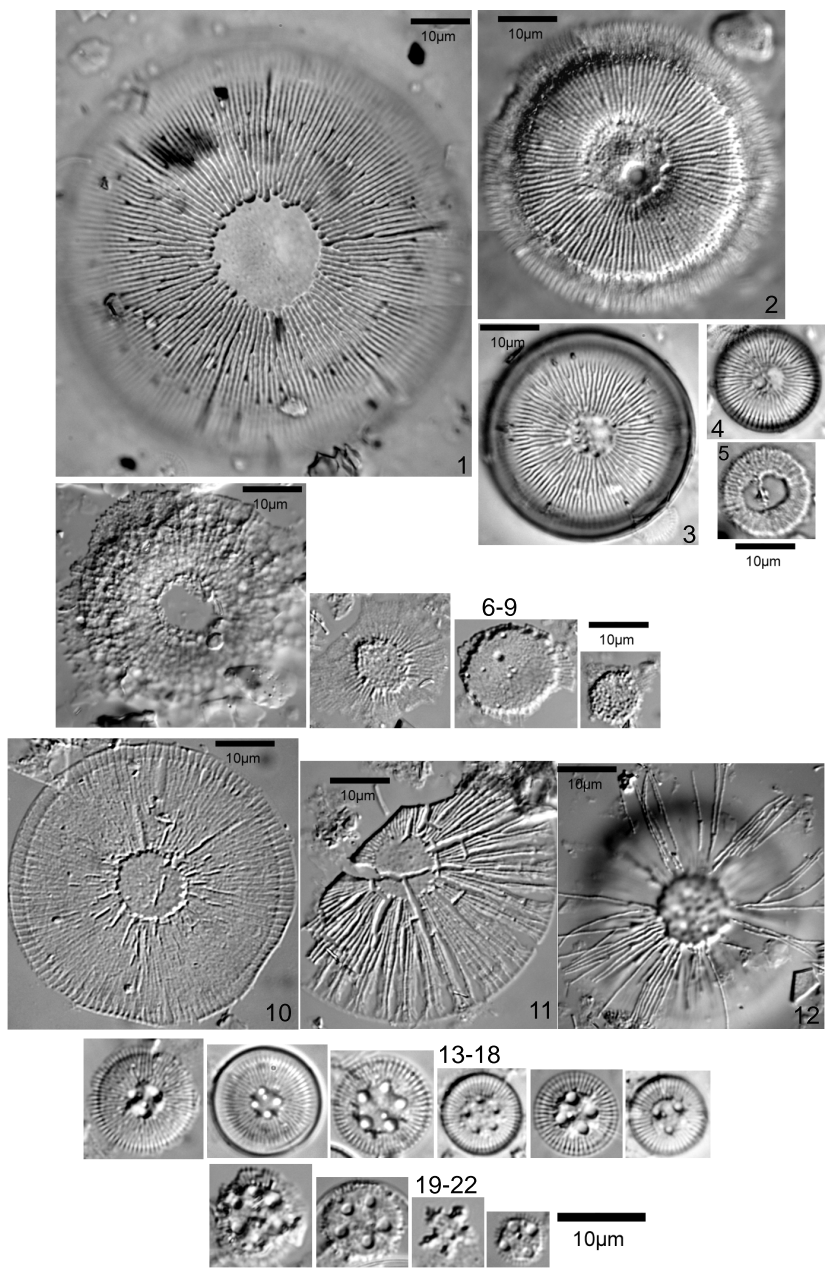

Fig. 3. Light micrographs of representative valves of Cyclotella fottii Hustedt (Figs. 1-12; $\times 1000$ magnification) and C. ocellata Pantocsek (Figs. 13-22; $\times 1500$ magnification). 1, 7-9, 10-12 classic dissolution series in $C$. fottii morphotype which lacks large central area (ca) depressions; 2-6 unusual dissolution series in $C$. fottii morphotype with large ca depressions. 13 classic $C$. ocellata with 3 ocelli; 144 ocelli, small round ca; 155 ocelli, pentagonal ca; 16 5 ocelli, irregular pentagonal ca; 174 ocelli, large circular ca; 18 3 ocelli, large circular ca; 19-22 C. ocellata dissolution series. (1 $122.2 \mathrm{~cm}$ depth; $2290 \mathrm{~cm} ; \mathbf{3 , 4} 145.5 \mathrm{~cm} ; \mathbf{5} 476.1 \mathrm{~cm} ; \mathbf{6} 242 \mathrm{~cm} ; \mathbf{7 - 9}$ $1299 \mathrm{~cm} ; \mathbf{1 0 - 1 1} 1198 \mathrm{~cm} ; \mathbf{1 2} 193.5 \mathrm{~cm} ; \mathbf{1 3 - 1 5}, \mathbf{1 9 - 2 2} 1299 \mathrm{~cm} ; \mathbf{1 6}$ $169.5 \mathrm{~cm} ; \mathbf{1 7} 169.5 \mathrm{~cm} ; \mathbf{1 8} 145.5 \mathrm{~cm}$.)

et al., 2009), it is clear that the two taxa described previously by Hustedt (1945) and Jurilj (1954) as C. fottii (valve diameter 40-90 $\mu \mathrm{m}$ ) and C. hustedtii (valve diameter 20-30 $\mu \mathrm{m}$ ), occur instead on a continuum, including in the range $<20 \mu \mathrm{m}$ and $30-40 \mu \mathrm{m}$, and have been merged as a consequence. Palaeolimnological variation in valve size could reflect important differences in limnological parameters such as mixing or light penetration, or the taxon may represent a species complex and should indeed be split at species level into var- ious size classes (cf. Flower, 1993). Similarly, C. ocellata is highly variable morphologically, and almost certainly represents a species complex (Håkansson, 2002). Since different morphotypes may exhibit different ecological preferences, numerous attempts have been made to explore variation according to parameters including valve diameter, number of ocelli and the morphology of the central area (e.g. Kiss et al., 1996; Hegewald and Hindáková, 1997; Cremer et al., 2005; Knie and Hübener, 2007; Genkal and Popovskaya, 2008).

The criteria for taxonomic splitting in Macedonia and the UK are summarized in Table 1. With the primary aim of investigating the changing presence and absence of taxa over time to feed into evolutionary studies, the Macedonian team split $C$. fottii into $10 \mu \mathrm{m}$ size classes. Since it is impossible to estimate valve diameter this accurately when the marginal area is dissolving, all partially-dissolved taxa were classed as "dissolved". In the UK, $C$. fottii was split at a lesser resolution into "large" (> ca. $20 \mu \mathrm{m}$ diameter) and "small" (< ca. $20 \mu \mathrm{m}$ diameter), allowing stages of dissolution (pristine, striae missing, central area plus few striae preserved) to be identified for each size class, with a smaller proportion of valves designated as "dissolved", where the valve diameter could not be discerned. In Macedonia, $C$. ocellata was split both by number of ocelli and by morphology of the central area, with a single dissolved category. To assign a larger proportion of valves to morphotypes, $C$. ocellata was split in the UK solely by number of ocelli, which can often be recognized in poorly-preserved specimens, using a 3-stage dissolution scale for each. Criteria were also set for taxonomic harmonization within the more diverse, and often endemic, facultative planktonic and benthic taxa, which have already been revised by Levkov et al. (2007). Since they are present at low abundance, the data for benthic taxa presented here are confined to the UK results; the Macedonian data form the focus for separate taxonomic study. In the plankton-dominated lake, following Wilson et al. (2008), a plankton-only dissolution scale was applied, to prevent skewed results from complete valves of robust taxa such as small Fragilariales. Counts were converted to percentage data and displayed using Tilia and TGView v. 2.0.2 (Grimm, 1991). Zone boundaries were defined with aid of Constrained Incremental Sum of Squares cluster analysis (Grimm, 1987).

Multivariate statistical techniques are often used to summarise variation in diatom data for palaeolimnological correlation and - importantly - for external correlation with global or regional palaeoclimate data. The influence of different splitting techniques on apparent variation in the diatom data was explored using indirect ordination techniques on three different diatom data-sets: UK unsplit (C. fottii and C. ocellata as single taxa), UK split and the full Macedonian split (Table 1), using the programs CANOCO (ter Braak and Šmilauer, 2002) and C2 v. 1.4.2 (Juggins, 2003). Initial detrended correspondence analysis gave gradient lengths of 1.4, 2.1 and 2.4, respectively. At a gradient length of $<2.5$, the appropriate ordination technique was selected as 
Table 1. Summary of criteria used for taxonomic splitting and dissolution stages of Cyclotella fottii and C. ocellata by laboratories in Macedonia and the UK.

\begin{tabular}{|c|c|c|c|}
\hline \multicolumn{4}{|l|}{ Cyclotella fottii } \\
\hline $\begin{array}{l}\text { Valve diameter classes } \\
(\mu \mathrm{m}), \text { Macedonia }\end{array}$ & Dissolution stages & $\begin{array}{l}\text { Valve diameter classes } \\
(\mu \mathrm{m}), \mathrm{UK}\end{array}$ & Dissolution stages \\
\hline$>50$, fine striae & 1. Identifiable to size class & $\geq 20$ & For each class: \\
\hline$>50$, coarse striae & 2. Dissolved, any size & & Pristine (margin intact) \\
\hline $40-50$ & & & Striae missing \\
\hline $\begin{array}{l}30-40 \\
20-30\end{array}$ & & $<20$ & $\begin{array}{l}\text { Central area plus few } \\
\text { striae to ID size }\end{array}$ \\
\hline $\begin{array}{l}10-20 \\
5-10\end{array}$ & & & $\begin{array}{l}\text { Central area, unassignable } \\
\text { to size }\end{array}$ \\
\hline \multicolumn{4}{|l|}{$<5$} \\
\hline \multicolumn{4}{|l|}{ Cyclotella ocellata } \\
\hline $\begin{array}{l}\text { Valve morphology, } \\
\text { Macedonia }\end{array}$ & Dissolution stages & Valve morphology, UK & Dissolution stages \\
\hline $\begin{array}{l}<5 \mu \mathrm{m} \\
6,5,4,3 \text { classic }\end{array}$ & 1. Assignable to group & $\begin{array}{l}<5 \mu \mathrm{m} \text { (no. ocelli } \\
\text { cannot be identified) }\end{array}$ & $\begin{array}{l}\text { For each class: } \\
\text { Pristine (rim intact) }\end{array}$ \\
\hline $\begin{array}{l}5,4,3 \text { undulating } \\
5,4,3 \text { small round } \\
6,5,4,3 \text { large round } \\
5 \text { irregular pentagon }\end{array}$ & $\begin{array}{l}\text { 2. Dissolved, } \\
\text { unassignable } \\
\text { to group }\end{array}$ & $\begin{array}{l}\text { Number of ocelli: } \\
3 \\
4 \\
5\end{array}$ & $\begin{array}{l}\text { Striae missing } \\
\text { Central area only } \\
\text { Dissolved, } \\
\text { unassignable }\end{array}$ \\
\hline $\begin{array}{l}5 \text { regular pentagon } \\
6,5,3 \text { irregular star } \\
5,4 \text { regular star } \\
4 \text { rhombic }\end{array}$ & & 6 & \\
\hline
\end{tabular}

correspondence analysis (CA) (Jongman et al., 1995), having established from analysis of the data-set with the shortest gradient length (UK unsplit) that the linear technique, principal components analysis, gave very similar results. Exploratory analysis also demonstrated the undue influence of a sample at $625.4 \mathrm{~cm}$ depth on the UK results. This sample comprised $100 \%$ dissolved $C$. fottii. Since this is not a defined morphotype, the variability is more an artefact of dissolution than taxonomic change, so the class was removed in the final CA analysis.

\section{Results}

\subsection{The influence of splitting techniques on diatom vari- ability}

Fifty-one diatom taxa were identified in the split UK data-set, compared to 92 taxa in the Macedonian data-set. The difference was due mainly to the additional criteria for splitting the two dominant planktonic taxa (Table 1) and in part to the more rigorous identification of rare valves $(<1 \%$ occurrence) of endemic taxa such as Diploneis spp. which were merged in UK counts. A comparative plot of Axis 1 scores (Fig. 4) shows that there is little effect of lumping versus splitting of C. fottii and C. ocellata in the UK data-set (34.6\% and $52.5 \%$ of the variance contained cumulatively in Axis 1 and Axis 2 for the lumped data, and $30.4 \%$ and $48.3 \%$ for the UK split). In spite of the major differences in counting techniques, there are only subtle differences in the pattern of variability compared to the Macedonian data $(35.1 \%$ and $50.2 \%$ of the variance contained cumulatively in Axis 1 and Axis 2). The Macedonian Axis 1 scores are more complacent, with major peaks of 2.6 and 1.2 at $1344.9 \mathrm{~cm}$ and $122.2 \mathrm{~cm}$, respectively, and a minor peak at $752.3 \mathrm{~cm}$. By splitting C. ocellata into 23 separate morphotypes, the phases dominated by this taxon have been over-emphasized. Diatom results presented below are based on analysis of the split UK data-set.

\subsection{Diatom analysis}

The summary diatom diagram (Fig. 5) shows that six major diatom assemblage zones (COD1 to COD6) can be defined using CONISS. Diatoms are sparse in zone COD1 (1489-1412.6 cm; ca. 135.4-127.4 ka), which is dominated 


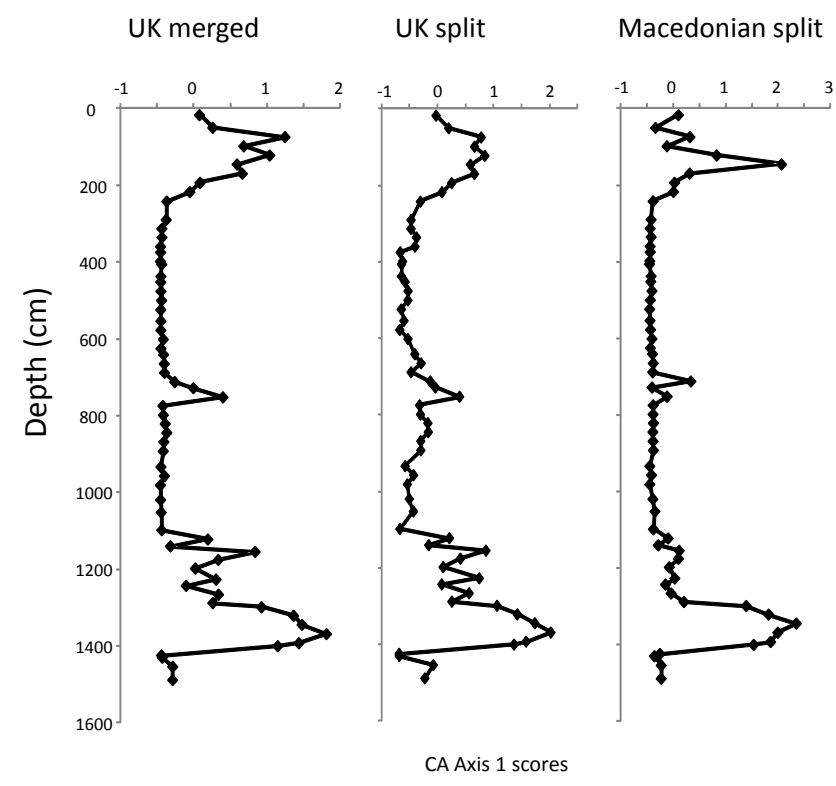

Fig. 4. Comparison of Axis 1 scores for correspondence analysis (CA) of the merged UK data-set (Cyclotella fottii and C. ocellata as single species), the UK split data-set and the Macedonian split data-set.

by $C$. fottii of both size classes. Other taxa are rare, including the planktonic Aulacoseira sp. (identified provisionally as the Balkan Miocene relict species, Melosira temperei Pantocek; Václav and Klee, 2007), small Fragilariales, including Staurosirella pinnata and Pseudostaurosira brevistriata, and a low diversity of benthic taxa including Amphora pediculus and Gomphonema pumilum. The poor preservation is not reflected well in the dissolution index, apart from at the top of the zone with partial preservation of large valves. Unlike most centrics, the striae and marginal area of $C$. fottii appears to be particularly robust. Some valves have large depressions in the central area, leading to the central area dissolving before the edge striae (Fig. 3); assemblages here also contain valves with the "classic" dissolution sequence leading to central area as the final stage.

A major biostratigraphic boundary marks the transition from COD1 to COD2 (1412.6-1110.4 cm; 127.4-99.0 ka), which is split into two subzones. In COD2a (1412.6$1310.2 \mathrm{~cm} ; 127.4-116.5 \mathrm{ka}$ ), the epilimnetic C. ocellata increases abruptly to become dominant at the expense of $C$. fottii, the occurrence of which is maintained as two morphotypes. C. ocellata valves with 5 and 4 ocelli are more common than those with 3 ocelli at the start of a zone; the transition to COD $2 b(1310.2-1110.4 \mathrm{~cm} ; 116.5-99.0 \mathrm{ka})$ is marked by the renewed dominance of $C$. fottii; $C$. ocellata is still common ( $>20 \%$ abundance), but with a marked decline in valves with 3 and 4 ocelli. Preservation is relatively good apart from at $1243.2-1227.2 \mathrm{~cm}$ depth; this is again not reflected clearly in the dissolution index, due to the increase in the percentage of dissolved centres as a consequence of the preservation of $C$. ocellata. As in COD1, a range of facultative planktonic and benthic taxa is present at very low abundance, but diversity is increased compared to zone COD1, by the presence of additional naviculoid taxa including the endemic Placoneis balcanica and Reimeria fontinalis, and by increased abundance of Amphora pediculus.

Cyclotella ocellata is absent in zone COD 3 (1110.4$913.5 \mathrm{~cm}$; $99.0-57.6 \mathrm{ka}$ ), which is dominated by poorlypreserved valves of large $C$. fottii. No transition in diatom species assemblage composition is discernible across the hiatus in the sequence between 1098.4-1052.1 cm depth. Facultative planktonic and benthic taxa are rare. The transition to COD4 (913.5-633.2 cm; 57.6-31.3 ka) is marked mainly by a transition to more well-preserved assemblages dominated by $C$. fottii, but also by the most consistent presence of $S$. pinnata, at $5-10 \%$ abundance. The sample at $821.5 \mathrm{~cm}$ depth marks a morphological transition to complete dominance in $C$. fottii of valves with large central area depressions, exhibiting an unusual dissolution sequence. Three samples in mid-zone have been separated by cluster analysis, as COD4b (763.5-700.4 cm; 40.8-35.0 ka); C. ocellata is present at $>20 \%$ abundance at $752.3 \mathrm{~cm}$ and at ca. $10 \%$ at $728.3 \mathrm{~cm}$, with a marked peak in facultative planktonic and benthic taxa across the subzone.

Zone COD5 (633.2-229.8 cm; 31.3-6.9 ka) marks a return to poorly-preserved assemblages dominated by large $C$. fottii, with rare Aulacoseira spp. in mid-zone, and rare facultative planktonic and benthic taxa. The transition at $347.6 \mathrm{~cm}$ $(13.8 \mathrm{ka})$ from COD5a to $5 \mathrm{~b}$ is marked more by preservation status, with an increase in dissolved $C$. fottii, and rare C. ocellata at the upper zone boundary. COD6 (229.8$17 \mathrm{~cm} ; 6.9-0.3 \mathrm{ka})$ is a major transition to a zone of good preservation of $C$. fottii, in which Stephanodiscus galileensis appears for the first time, consistently at $>10 \%$ abundance, and $C$. ocellata, which is now dominated by "classic" valves with 3 ocelli. Cyclotella ocellata increases to a peak of $45 \%$ at $122.2 \mathrm{~cm}$, after which $C$. fottii increases towards the top of the sequence at the expense of $C$. ocellata (5-10\%) and S. galileensis (ca. 5\%). A wider range of facultative planktonic and benthic taxa is again present, with a notable $15 \%$ peak in Gomphonema pumilum at $74.2 \mathrm{~cm}$ depth.

\section{Discussion}

Summary diatom data are compared chronologically with selected data from Vogel et al. (2010b) and with marine isotope stage boundaries in Fig. 6. Tephra layers at 1,447-1,440 cm, $825-822 \mathrm{~cm}, 696-689 \mathrm{~cm}, 620-617 \mathrm{~cm}$ and $277.5-269 \mathrm{~cm}$ are also marked, none of which correlates with diatom zone boundaries to suggest volcanic rather than climatic influence. In general, the strong correlation between diatom ecological and geochemical variability over much of the sequence attests to the combined strength of the proxy indicators. 


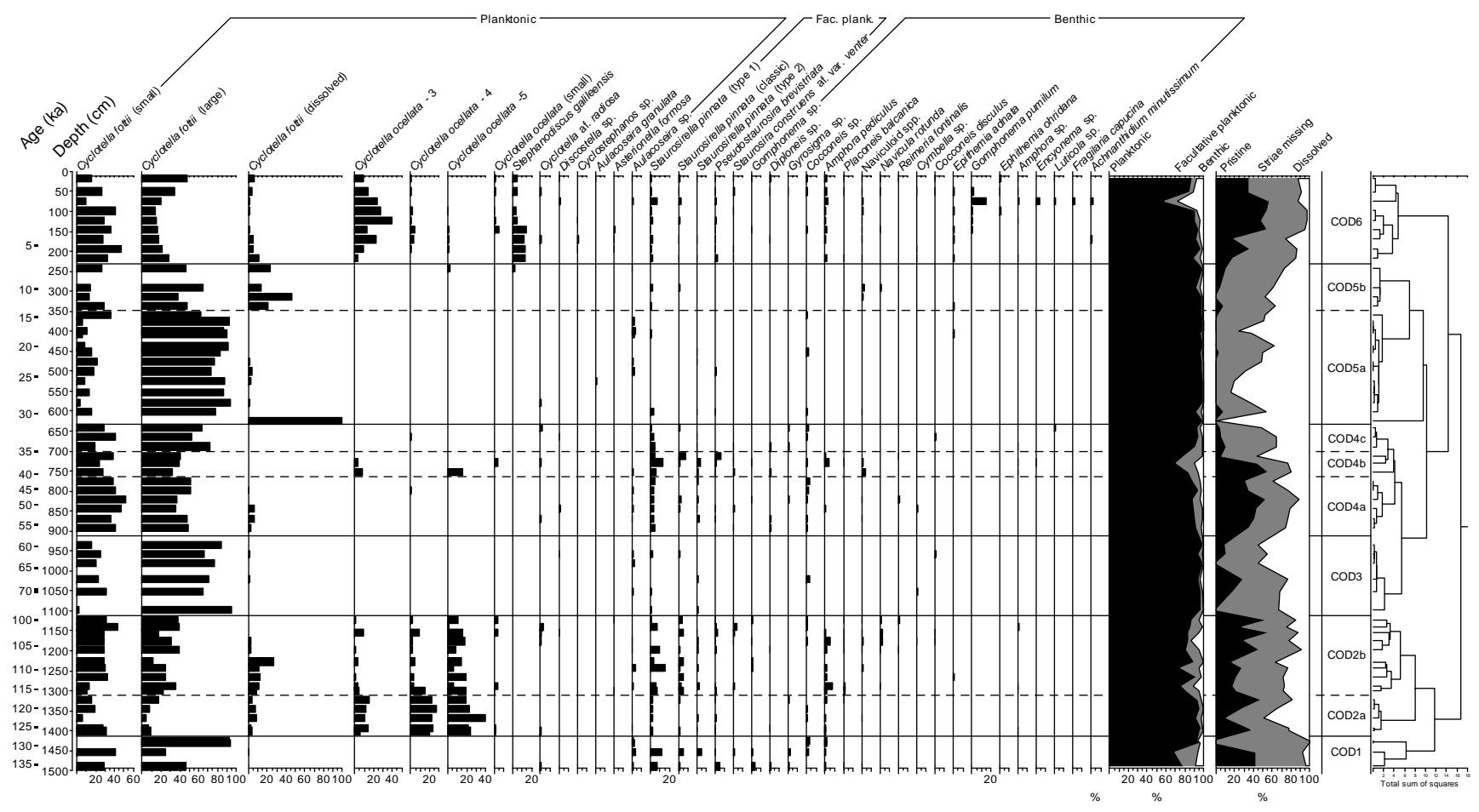

Fig. 5. Summary diatom diagram showing taxa present at $>1 \%$ abundance in core Co1202, the proportion of planktonic, facultative and benthic taxa and proportions of taxa in different dissolution stages. Zones were defined by CONISS.

\subsection{Palaeoclimate reconstruction}

\subsubsection{The penultimate glacial, MIS6: COD1 (1489-1412.6 cm; ca. 135.4-127.4 ka)}

Following previous Ohrid studies (Roelofs and Kilham, 1983; Wagner et al., 2009), the dominance and poor preservation of $C$. fottii in diatom zone COD1 reflects cold, glacial conditions at the end of MIS6. As noted by Vogel et al. (2010b) this is in accord with pollen-based temperature estimates (Allen and Huntley, 2009). The Termination II transition occurs at $127.3 \mathrm{ka}$ in the diatom record, matching exactly the transition in the lithofacies approach of Vogel et al. (2010b). From Fig. 6, the trend towards increasingly high CA Axis 1 scores (tracking $C$. ocellata) correlates with the carbonate curve, starting below the upper COD1 zone boundary, and correlating with an absence of ice-rafted debris from ca. $130 \mathrm{ka}$ (Vogel et al., 2010b). Together, the proxies show strong evidence for global climate change, with the onset of MIS5e sensu stricto (130 $\pm 2 \mathrm{ka}$; Hearty et al., 2007).

\subsubsection{MIS 5: COD2 $(1412.6-1110.4 \mathrm{~cm} ; 127.4-99.0 \mathrm{ka})$}

In MIS5, the increasing dominance of epilimnetic $C$. ocellata suggests the delayed onset of stable, warm surface waters after $130 \mathrm{ka}$, in support of the previous geochemical interpretation of a stepwise transition (Vogel et al., 2010b); the initial transition to high abundance of $C$. ocellata appears more abrupt than in geochemical indicators, but at this resolution (ca. $2.5 \mathrm{ka}$ between diatom subsamples) the data are not definitive. The prolonged diatom-inferred warm, stable phase in COD2a $(1412.6-1310.2 \mathrm{~cm} ; 127.4-116.5 \mathrm{ka})$ correlates with trends towards maxima in biogenic silica and carbonate content, suggesting sustained temperature increase during the spring and summer.

COD 2b (1310.2-1110.4 cm; 116.5-99.0 ka) is marked by the renewed dominance of $C$. fottii, indicative of cooling, and is again matched by a decreasing biogenic silica and sediment calcite content. The consistent presence of small Fragilariales and benthic taxa in COD2b may indicate the development of diatom communities in the littoral zone with reduction in ice cover (cf. Smol and Douglas, 2007). It is possible that the apparent lack of littoral communities in COD2a, where they would also be predicted to peak, is an artefact of a higher relative abundance of $C$. ocellata with development of epilimnetic communities during peak warming. This interpretation would be supported by higher diatom accumulation rates in COD2a, indicative of higher productivity in a zone of good diatom preservation, and remains to be tested. As a note of caution, small Fragilariales alone are poor environmental indicators, often dominating glacial rather than interglacial assemblages of Mediterranean lakes (cf. Lake Ioannina, Greece; Wilson et al., 2008) and even here they are present in the glacial assemblages of COD1. The benthic taxa are sufficiently rare that they also do not provide 


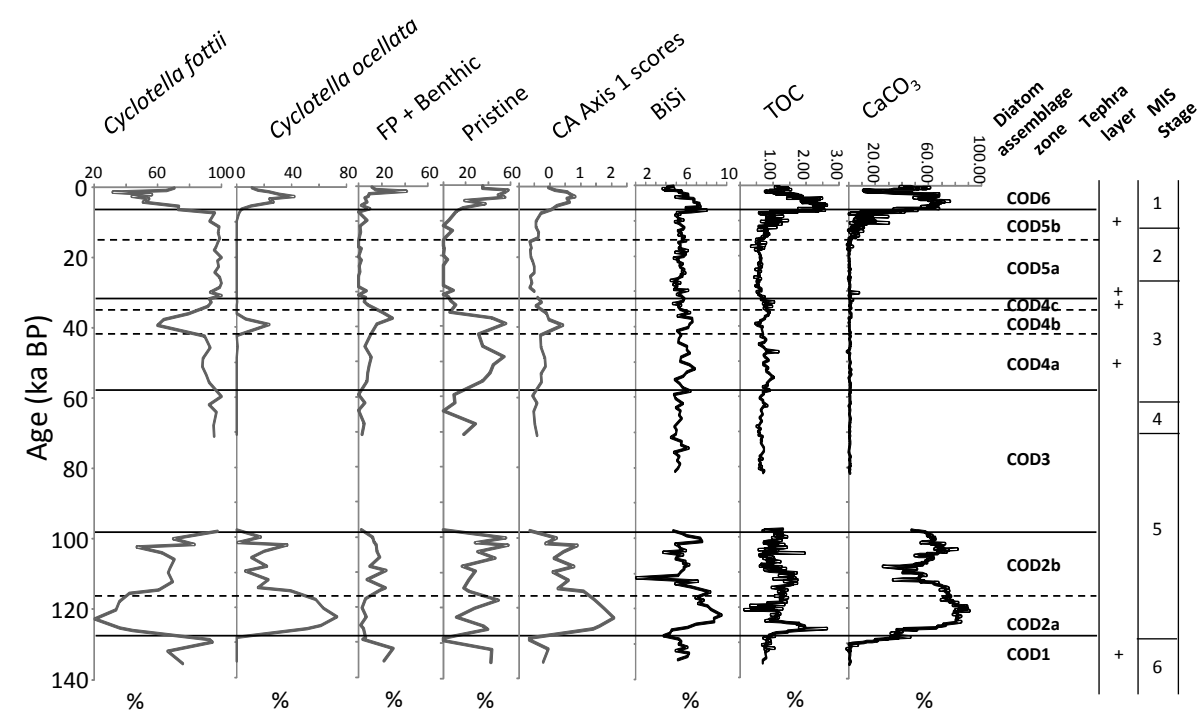

Fig. 6. Comparison of summary diatom data with selected geochemical data from Vogel et al. (2010b), on a chronological timescale, showing the location of major tephra layers. $(\mathrm{FP}=$ facultative planktonic; $\mathrm{CA}=$ correspondence analysis; $\mathrm{BiSi}=$ biogenic silica; $\mathrm{TOC}=$ total organic carbon; $\mathrm{CaCO}_{3}=$ calcium carbonate, measured by loss on ignition). Boundary ages of Marine Isotope Stages (MIS stages) from Imbrie et al. (2007) are shown for comparison.

very strong supporting evidence, in a sequence where relative abundance may have been affected by poor preservation in glacial phases.

The inferred minimum temperature at $108.4 \mathrm{ka}$ in geochemical data (indicated tentatively by a stepwise reduction in calcite; Vogel et al. 2010b) correlates with a peak of $>20 \%$ rather than a minimum in $C$. ocellata, suggesting correlation with the North Atlantic C24 event (Vogel et al., 2010) might be unreliable; higher resolution diatom analysis would elucidate this. A short-lived trend towards rising C. ocellata abundance correlates well with geochemical data indicative of renewed warming thereafter, in interstadial MIS 5.3 (Vogel et al., 2010b). Vogel et al. (2010b) note the close correlation with the inferred pattern of climate change from Lago Grande di Monticchio (Brauer et al., 2007). Further afield, the diatom-based inferences correlate broadly with the start of an inferred cooling trend seen after ca. $119 \mathrm{ka}$ in Lake Baikal, but which peaks in the case of Baikal at ca. 117$115 \mathrm{ka}$ (Rioual and Mackay, 2005; Prokopenko et al., 2006; Mackay, 2007). This marks the end of MIS5d, the peak of the Last Interglacial (119 $\pm 2 \mathrm{ka}$; Hearty et al., 2007).

\subsubsection{MIS 4-2: COD3-COD5a (1110.4-347.6 cm; 99.0-13.8 ka)}

The Last Glacial period is clearly recorded in the diatom record, with maximum cooling indicated during the Last Glacial Maximum, MIS2, by very poor preservation of C. fottii in COD5a.
The diatom record is outstanding in providing the first clear evidence for warming during interstadial MIS3, during COD 4 (57.6-31.3 ka), culminating in a minor peak in C. ocellata at $39.3 \mathrm{ka}$ (COD4b) indicative of warming. Previously, minor associated peaks in biogenic silica and organic content were considered inconclusive, but this study suggests their significance. The first geochemical results from the shallower feeder lake, Lake Prespa (Wagner et al., 2010) demonstrate a more marked signal for this phase, but the authors initial conclusion that the event is not marked in Ohrid was premature; it supports the inference that diatoms respond rapidly and sensitively to warming. In addition, the earlier consistent presence of small Fragilariales from the start of COD4 supports, more convincingly than in COD1, an interpretation of reduced ice cover with less pronounced warming from ca. $58 \mathrm{ka}$, correlating very well with the start of MIS3 in the marine record at $59 \mathrm{ka}$ (Imbrie et al., 2007). C. ocellata developed later, following basin-wide warming of surface waters. The value of these proxies is all the more important because oxygen and carbon stable isotope data cannot be generated in glacial phases due to low carbonate content (Leng et al., 2010) and ostracods are absent offshore in glacial phases (A. Schwalb, personal communication).

The COD4b subzone also correlates approximately with the basal diatom zone (D1) of the Lz1120 sequence, which is co-dominated by well preserved assemblages of $C$. ocellata and Discostella stelligera (ca. 38.7-37.5 ka) prior to major inferred cooling (Wagner et al., 2009). Represented by only two samples, and without supporting geochemical variation, this had previously been interpreted with caution. D. stelligera is absent in Co1202, and Lz1120 is also distinguished 
by the greater dominance over $C$. fottii of epilimnetic plankton $(>40 \%)$ and in number and abundance of benthic taxa. This might reflect spatial variability across the basin due to differences in interlinked parameters such as river and spring discharge, nutrient input, temperature, water depth, distance from the littoral zone or mixing. The Co1202 site (145 m water depth) is deeper than Lz1120 (105 m); TOC/TS indicates less oxic bottom waters in the former as they are close to or below the summer thermocline in the modern lake, with additional evidence from lipid biomarkers for differences in river discharge (Holtvoeth et al., 2010). Equally, the differences may be due to the effects of enhanced dissolution in Co1202; Lz1120 had a higher sediment accumulation rate (Holtvoeth et al., 2010), but slightly reduced mixing conditions in Co1202 would be more likely to favour preservation in the sediment record. If dissolution is a factor, this suggests it is likely to have occurred in the sediment column, prior to burial. A transect-based diatom study and, as noted, dissolution studies, would allow these hypotheses to be tested in more detail.

\subsubsection{Last glacial-interglacial transition and the Holocene: COD5b-COD 6 (347.6-17.0 cm; 13.8-0.3 ka)}

It is surprising that the diatom record does not show a strong response to Late Glacial warming from $14.7 \mathrm{ka}$, leading up to the Holocene transition at $11.7 \mathrm{ka}$. Instead, COD5b (13.8$6.9 \mathrm{ka}$ ) shows closer affinity with glacial phases, being dominated by $C$. fottii. This is clearly in part a function of extremely sparse assemblages with poor diatom preservation in the upper three samples of COD5 (prior to $6.9 \mathrm{ka}$ ). Again, diatom accumulation data would demonstrate this more clearly. While the CA Axis 1 scores do appear to show the predicted trend towards higher values in COD5b, correlating with a trend in organic and carbonate content from ca. $15 \mathrm{ka}$, the lack of response in C. ocellata is mirrored by complacently low biogenic silica prior to ca. $7 \mathrm{ka}$. Taken at face value, the data indicate that rapid "Holocene" warming did not occur until the mid-Holocene. The sediment record does show evidence for the maintained deposition of ice-rafted debris during the Late Glacial, to support this (Vogel et al., 2010b). In the light of the diatom sensitivity to earlier climate fluctuations, and to the clear diatom-inferred evidence for warming by $9.4 \mathrm{ka}$ after a hiatus in core Lz1120 (Wagner et al., 2009), however, it is more likely that the sequence is compromised during this phase in core Co1202. It is not possible to test the impact of the well known climatic reversals of the Younger Dryas and $8.2 \mathrm{ka}$ event (which here has not been sampled for diatoms). The resolution of the diatom record in this study is also too low to comment on abrupt change during the Holocene. It is notable for the first appearance of Stephanodiscus galileensis in the record, possibly indicating greater nutrient enrichment than in the previous interglacial. This declines in the post-Medieval period (last ca. 2000 years), which shows a rise in $C$. fottii. The maintenance of the more thermophilic planktonic taxa, and the peak in facultative planktonic and benthic taxa, indicate this is not a return to full glacial conditions. Equally, C. fottii is present in the lake today; the increase in relative abundance cannot be explained simply by cooling, and underlines the challenge in interpreting these low diversity assemblages in terms of climate change. A possible mechanism would be weaker thermal stratification during the Late Holocene, reducing productivity in the epilimnion.

\subsection{Diatom dissolution}

The 3-point plankton diatom dissolution index adopted here proved not to be very sensitive, due in part to the unusual and temporally variable dissolution series of $C$. fottii, with its robust edge striae and margin, and to the preservation of small, relatively fragile dissolving centres of $C$. ocellata in zones of good preservation. The percentage of pristine, complete planktonic valves in Fig. 6 does track broad shifts from interglacial (high) to glacial (low preservation), and shows a clear minimum during the Last Glacial Maximum (COD5), supporting indirectly the interpretation of maximum cooling during this phase. Since the proportion of facultative planktonic and benthic taxa is so low, the profile is similar to that which would be produced using all valves, a simple index which has proved to be effective in Baikal studies, and is termed the F index (Mackay et al., 1998). For the future, a more detailed (e.g. 3-stage; cf. Ryves et al., 2006) dissolution index adapted to incorporate the unusual dissolution behaviour of $C$. fottii may prove more effective in tracking preservation. Very clearly, it would also be useful to combine this approach with the calculation of absolute diatom concentration and flux (Battarbee and Kneen, 1982).

The degree to which dissolution may have biased species assemblage composition is difficult to assess. Asterionella formosa, for example, is common in the modern lake (Levkov et al., 2007) but almost absent in the sediment record. While the results support the integrity of diatoms as a sensitive tracer of climate change, further studies are necessary (cf. Ryves et al., 2003) to test how far assemblages may be affected by taphonomic processes operating in the water column and sediment record.

\subsection{Morphological variability}

The intriguing shift in central area morphology of $C$. fottii, which was observed clearly at $821.5 \mathrm{~cm}$ by both laboratories, occurred at ca. $48.7 \mathrm{ka}$, immediately after deposition of a tephra layer. It is unlikely that a single eruption would cause a permanent morphological shift, because major physicochemical change would be predicted also to cause ecological shifts in species assemblage composition. Exploring other potential effects of diatom evolution and their correlation to inferred environmental change, $C$. fottii does not appear to 
show any significant trends in size classes other than those related to dissolution effects, such that the Last Glacial Maximum is dominated by larger, more robust valves. There is insufficient space here to report the full Macedonian results, but the lack of variability between $10 \mu \mathrm{m}$ size intervals is reflected in the complacency of CA Axis 1 scores during glacial phases (Fig. 4).

In contrast, $C$. ocellata exhibits a major shift from dominance by valves with 5 ocelli during the Last Interglacial, to valves with 3 ocelli in the Holocene. The presence of pristine valves with unusual central area morphology (unpubl. Macedonian data) is also more common in the Last Interglacial. The shift suggests climatically-forced variation or some other form of evolutionary selection pressure. A simple climatic explanation is unlikely; while some limnological studies have found a relationship between the size of $\mathrm{C}$. ocellata and water chemistry dynamics (e.g. Schlegel and Scheffler, 1999), which could be influenced by long-term climate change, other limnological (e.g. Cremer et al., 2005) and palaeolimnological studies (e.g. Cherapanova et al., 2007) have found variation in size and/or number of ocelli to vary independently of environmental change, and morphological variation has even been found to occur across a single lake basin (Edlund et al., 2003).

\section{Conclusions}

In advance of an ICDP deep drilling project, this study demonstrates clearly the response of Lake Ohrid to global climate change. As in Lake Baikal, the results are outstanding in demonstrating the sensitivity of diatoms to climate change, providing proxy evidence for the character of temperature change during the Last Interglacial, and much stronger evidence in this site for warming during MIS3 than recorded in other productivity related proxies. Higher resolution studies will be necessary to test the impact of more abrupt climate events, and to establish in more detail the character of glacial-interglacial transitions, which appear abrupt at this relatively low resolution. We have also suggested that the Late Glacial-mid-Holocene record may be compromised in Co1202, as a more likely explanation than basin-wide differences in ice cover between Co1202 and LZ1120. The proposed deep drilling project should provide a third Ohrid core site by which to test this and other competing hypotheses raised in this paper. There is clear potential for more detailed studies of evolution and endemism, to test whether diatoms are tracking climate change or are responding to different evolutionary selection pressures, and the study has been successful in setting up taxonomic protocols for future research.
Acknowledgements. JMR would like to thank Antje Schwalb warmly for inviting collaboration on this project. The help of John Garner (Hull) in producing the Ohrid map is greatly appreciated. The three referees, Holger Cremer, Anson Mackay and David Ryves, are also thanked warmly for providing such detailed and constructive comments on the manuscript.

Edited by: T. Wilke

\section{References}

Albrecht, C. and Wilke, T.: Ancient Lake Ohrid: biodiversity and evolution, Hydrobiol., 615, 103-140, 2008.

Allen, J. R. M. and Huntley, B.: Last Interglacial palaeovegetation, palaeoenvironments and chronology: a new record from Lago Grande di Monticchio, southern Italy, Quaternary Sci. Rev., 28, 1521-1538, 2009.

Allen, J. R. M., Brandt, U., Brauer, A., Hubberten, H-W., Huntley, B., Keller, J., Kraml, M., Mackensen, A., Mingram, J., Negendank, J. F. W., Nowaczyk, N. R., Oberhansli, H., Watts, W. A., Wulf, S., and Zolitschka, B.: Rapid environmental changes in southern Europe during the last glacial period, Nature, 400, 740743, 1999.

Ampel, L., Wohlfarth, B., Risberg, J., and Veres, D.: Paleolimnological response to millennial and centennial scale climate variability during MIS 3 and 2 as suggested by the diatom record in Les Echets, France, Quaternary Sci. Rev., 27, 1493-1504, 2008.

Battarbee, R. W.: Diatom analysis, in: Handbook of Holocene Palaeoecology and Palaeohydrology, edited by: Berglund, B. E., Wiley, Chichester, 527-570, 1986.

Battarbee, R. W. and Kneen, M. J.: The use of electronically counted microspheres in absolute diatom analysis, Limnol. Oceanogr., 27, 184-188, 1982.

Brauer, A., Allen, J. R. M., Mingram, J., Dulski, P., Wulf, S., and Huntley, B.: Evidence for last interglacial chronology and environmental change from Southern Europe, Proc. Nat. Acad. Sci., 104, 450-455, 2007.

Broecker, W. S.: Massive iceberg discharges as triggers for global climate change, Nature, 372, 421-424, 2002.

Cacho, I., Grimalt, J. O., Pelejero, C., Canals, M., Sierro, F. J., Flores, J. A., and Shackleton, N.: Dansgaard-Oeschger and Heinrich event imprints in Alboran Sea paleotemperatures, Paleoceanogr., 14, 698-705, 1999.

Cherapanova, M. V., Snyder, J. A., and Brigham-Grette, J.: Diatom stratigraphy of the last $250 \mathrm{ka}$ at Lake El'gygytgyn, northeast Siberia, J. Paleolimnol., 37, 155-162, 2007.

Cremer, H., Wagner, B., Juschus, O., and Melles, M.: A microscopical study of diatom phytoplankton in deep crater Lake El'gygytgyn, Northeast Siberia, Algological Studies, 116, 147$169,2005$.

Digerfeldt, G., Olsson, S., and Per Sandgren, P.: Reconstruction of lake-level changes in Lake Xinias, central Greece, during the last 40000 years, Palaeogeogr. Palaeoecol., 158, 65-82, 2000.

Edlund, M. B., Williams, R. M., and Soninkhishig, N.: The planktonic diatom diversity of ancient Lake Hovsgol, Mongolia. Phycologia, 42, 232-260, 2003.

Flower, R. J.: A taxonomic re-evaluation of endemic Cyclotella taxa in Lake Baikal, Nova Hedwigia, 106, 203-220, 1993. 
Genkal, S. I. and Popovskaya, G. I.: Morphological variability of Cyclotella ocellata from Lake Khubsugul (Mongolia), Diatom Res., 23, 75-91, 2008.

González-Sampériz, P., Valero-Garcés, B. L., Carrión, J. S., PeñaMonné, J. L., García-Ruiz, J. M., and Martí-Bono, C.: Glacial and Lateglacial vegetation in northeastern Spain: New data and a review, Quatern. Int., 140-141, 4-20, 2005.

Grimm, E. C.: CONISS: A FORTRAN 77 program for the stratigraphically constrained cluster analysis by the method of incremental sum of squares, Comput. Geosci., 13, 13-35, 1987.

Grimm E. C.: TILIA and TILIA-GRAPH, Illinois State Museum, Springfield, USA, 1991.

Håkansson, H.: A compilation and evaluation of species in the genera Stephanodiscus, Cyclostephanos and Cyclotella with a new genus in the family Stephanodiscaceae, Diatom Res., 17, 1-139, 2002.

Hearty, P. J., Hollin, J. T., Neumann, A. C., O'Leary, M. J., and McCulloch, M.: Global sea-level fluctuations during the Last Interglaciation (MIS 5e), Quaternary Sci. Rev., 26, 2090-2112, 2007.

Hegewald, E. and Hindáková, A.: Variability of a natural population and clones of the Cyclotella ocellata-complex (Bacillariophyceae) from the Gallberg-pond, NW-Germany, Algological Studies, 86, 17-37, 1997.

Holtvoeth, J., Vogel, H., Wagner, B., and Wolff, G. A.: Lipid biomarkers in Holocene and glacial sediments from ancient Lake Ohrid (Macedonia, Albania), Biogeosciences Discuss., 7, 46074640, doi:10.5194/bgd-7-4607-2010, 2010.

Hustedt, F.: Diatomeen aus Seen und Quellgebieten der BalkanHalbinsel, Arch. Hydrobiol, 40, 867-973, 1945.

Imbrie, J., Hays, J. D., Martinson, D. G., McIntyre, A., Mix, A. C., et al.: the orbital theory of Pleistocene climate: support from a revised chronology of the marine $\delta^{18} \mathrm{O}$ record, in: Milankovitch and Climate (Pt. 1), edited by: Berger, A. L., Imbrie, J., Hays, J. D., Kukla, G., and Saltzman, B.: Dordrecht, Reidel, 269-305, 2007.

Jongman, R. H. G., ter Braak, C. J. F., and van Tongeren, O. F. R.: Data analysis in community and landscape ecology, Cambridge University Press, Cambridge, 1995.

Juggins, S.: C2 User guide. Software for ecological and palaeoecological data analysis and visualisation ( $\mathrm{C} 2$ version 1.4 .3 , build 1), University of Newcastle, Newcastle upon Tyne, 2003.

Jurilj, A.: Flora i vegetacija dijatomeja Ohridskog jezera, (Flora and vegetation of diatoms from Ohrid Lake in Yugoslavia), JAZU (Yugoslavian Academy of Science), Zagreb, 26, 99-190, 1954.

Kiss, K. T., Rojo, C., and Álvarez-Cobelas, M.: Morphological variability of a Cyclotella ocellata (Bacillariophyceae) population in the Lake Las Madres (Spain), Algological Studies, 82, 37-55, 1996.

Knie, M. and Hübener, T.: Morphological variability of the $C y$ clotella ocellata-krammeri-rossii complex in field samples and cultures, in: Proceedings of the 1st Central European Diatom Meeting, edited by: Kusber, W.-H. and Jahn, R., Botanic Museum, Berlin, 2007.

Krammer, K. and Lange-Bertalot, H.: Süsswasserflora von Mitteleuropa. Bacillariophyceae. 1. Teil: Naviculaceae (Vol. 2/1), Gustav Fischer Verlag, Stuttgart, 1986.

Krammer, K. and Lange-Bertalot, H.: Süsswasserflora von Mitteleuropa. Bacillariophyceae. 2. Teil: Epithemiaceae, Bacillariaceae, Surirellaceae (Vol. 2/2), Gustav Fischer Verlag, Stuttgart,
1988.

Krammer, K. and Lange-Bertalot, H.: Süsswasserflora von Mitteleuropa. Bacillariophyceae. 3. Teil: Centrales, Fragilariaceae, Eunotiaceae (Vol. 2/3), Gustav Fischer Verlag, Stuttgart, 1991a.

Krammer, K. and Lange-Bertalot, H.: Süsswasserflora von Mitteleuropa. Bacillariophyceae. 4. Teil: Achnanthaceae (Vol. 2/4), Gustav Fischer Verlag, Stuttgart, 1991b.

Krammer, K. and Lange-Bertalot, H.: Süsswasserflora von Mitteleuropa. Bacillariophyceae. 5. English and French translation of the keys (Vol. 2/5), Gustav Fischer Verlag, Stuttgart, 2000.

Lawson, I., Frogley, M., Bryant, C., Preece, R., and Tzedakis, P.: The Lateglacial and Holocene environmental history of the Ioannina basin, north-west Greece, Quaternary Sci. Rev., 23, 15991625, 2004.

Leng, M. J., Baneschi, I., Zanchetta, G., Jex, C. N., Wagner, B., and Vogel, H.: Late Quaternary palaeoenvironmental reconstruction from Lakes Ohrid and Prespa (Macedonia/Albania border) using stable isotopes, Biogeosciences Discuss., 7, 3815-3853, doi:10.5194/bgd-7-3815-2010, 2010.

Levkov, Z., Krstic, S., Metzeltin, D., and Nakov, T.: Diatoms of Lakes Prespa and Ohrid. About 500 taxa from ancient lake system, Iconographia Diatomologica, 16. ARG Gantner Verlag, Germany, 2007.

Mackay, A.: The paleoclimatology of Lake Baikal: a diatom synthesis and prospectus, Earth Sci. Rev., 82, 181-215, 2007.

Mackay, A. W., Flower, R. J., Kuzmina, A. E., Granina, L. Z., Rose, N. L., Appleby, P. G., Boyle, J. F., and Battarbee, R. W.: Diatom succession and pollution trends in recent sediments from Lake Baikal and their relation to atmospheric pollution and to climate change, Philos. T. R. Soc. Lond. B, 353, 1011-1055, 1998.

Matter, M., Anselmetti, F. S., Jordanoska, B., Wagner, B., Wessels, M., and Wüest, A.: Carbonate sedimentation and effects of eutrophication observed at the Kališta subaquatic springs in Lake Ohrid (Macedonia), Biogeosciences Discuss., 7, 47154747, doi:10.5194/bgd-7-4715-2010, 2010.

Matzinger, A., Spirkovski, Z., Patceva, S., and Wüest, A.: Sensitivity of ancient Lake Ohrid to local anthropogenic impacts and global warming, J. Great Lakes Res., 32, 158-179, 2006.

Matzinger, A., Schmid, M., Veljanoska-Sarafiloska, E., Patceva, S., Guseka, D., Wagner, B., Sturm, M., Müller, B., and Wüest, A.: Assessment of early eutrophication in ancient lakes - A case study of Lake Ohrid, Limnol. Oceanogr., 52, 338-353, 2007.

Ocevski, B. T. and Allen, H. L.: Limnological Studies in a Large, Deep, Oligotrophic Lake (Lake Ohrid, Yugoslavia), Arch. Hydrobiol., 79, 429-440, 1977.

OECD: Eutrophication of waters. Monitoring assessment and control, OECD, Paris, 1982.

Prokopenko, A. A., Hinnnov, L. A., Williams, D. F., and Kuzmin, M. I.: Orbital forcing of continental climate during the Pleistocene: a complete astronomically tuned climatic record from Lake Baikal, SE Siberia, Quaternary Sci. Rev., 25, 3431-3457, 2006.

Rioual, P., Andrieu-Ponel, V., de Beaulieu, J. L., Reille, M., Svobodova, H., and Battarbee, R. W.: Diatom responses to limnological and climatic changes at Ribains Maar (French Massif Central) during the Eemian and Early Würm, Quaternary Sci. Rev., 26, 1557-1609, 2007.

Rioual, P. and Mackay, A. W.: A diatom record of centennial resolution for the Kazantsevo Interglacial stage in Lake Baikal 
(Siberia), Global Planet. Change, 46, 199-219, 2005.

Roelofs, A. K. and Kilham, P.: The diatom stratigraphy and paleoecology of Lake Ohrid, Yugoslavia, Palaeogeogr. Palaeoecol., 42, 225-245, 1983.

Ryves, D. B., Jones, V. J., Guilizzoni, P., Lami, A., Marchetto, A., Battarbee, R. W., Bettinetti, R., and Devoy, E. C.: Late Pleistocene and Holocene environmental changes at Lake Albano and Lake Nemi (central Italy) as indicated by algal remains, in: Paleoenvironmental Analysis of Italian Crater Lakes (PALICLAS), edited by: Guilizzoni, P. and Oldfield, F., Memorie dell'Istituto Italiano di Idrobiologia, 55, 1996.

Ryves, D. B., Jewson, D. H., Sturm, M., Battarbee, R. W., Flower, R. J., Mackay, A. W., Granin, N. G.: Quantitative and qualitative relationships between plantonic diatom communities and diatom assemblages in sedimenting material and surface sediments in Lake Baikal, Siberia, Limnol. Oceanogr., 48, 1643-1661, 2003.

Ryves, D. B., Battarbee, R. W., Juggins, S., Fritz, S. C. and Anderson, N. J.: Physical and chemical predictors of diatom dissolution in freshwater and saline lake sediments in North America and West Greenland, Limnol. Oceanogr., 51, 1355-1368, 2006.

Schlegel, I. and Scheffler, W.: Seasonal development and morphological variability of Cyclotella ocellata (Bacillariophyceae) in the eutrophic Lake Dagow, Germany, Internat. Rev. Hydrobiol., 84, 469-478, 1999.

Smol, J. P. and Douglas, M. S. V.: From controversy to consensus: making the case for recent climate change in the Arctic using lake sediments, Front. Ecol. Environ., 5, 466-474, 2007.

Stankovic, S.: The Balkan Lake Ohrid and its living world, Monographiae Biologicae, IX, Dr. W. Junk, Den Haag, 1960.

Sulpizio, R., Zanchetta, G., D’Orazio, M., Vogel, H., and Wagner, B.: Tephrostratigraphy and tephrochronology of lakes Ohrid and Prespa, Balkans, Biogeosciences Discuss., 7, 3931-3967, doi:10.5194/bgd-7-3931-2010, 2010.

ter Braak, C. J. F. and Šmilauer, P.: CANOCO reference manual and CanoDraw for Windows user's guide, Biometris, Wageningen, 2002.

Tierney, J. E., Russell, J. M., Huang, Y. S., Damste, J. S. S., Hopmans, E. C., and Cohen, A. S.: Northern Hemisphere controls on tropical southeast African climate during the past 60,000 years, Science, 322, 252-255, 2008.

Tzedakis, P. C.: Towards an understanding of the response of southern European vegetation to orbital and suborbital climate variability, Quaternary Sci. Rev., 24, 1585-1599, 2005.

Tzedakis, P. C.: Seven ambiguities in the Mediterranean palaeoenvironmental narrative, Quaternary Sci. Rev., 26, 2042-2066, 2007.
Tzedakis, P. C., Frogley, M. R., Lawson, I. T., Preece, R. C., Cacho, I., and de Abreu, L.: Ecological thresholds and patterns of millennial-scale climate variability: the response of vegetation in Greece during the last Glacial period, Geology, 32, 109-112, 2004.

Václav, H. and Klee R.: Atlas of freshwater centric diatoms with a brief key and descriptions. Part II. Melosiraceae and Aulacoseiraceae (Supplement to Part I), Fottea 7, 85-255, 2007.

Vogel, H., Zanchetta, G., Sulpizio, R., Wagner, B., and Nowaczyk, N.: A tephrostratigraphic record for the last glacial-interglacial cycle from Lake Ohrid, Albania and Macedonia, J. Quaternary Sci., 25, 320-338, 2010a.

Vogel, H., Wagner, B., Zanchetta, G., Sulpizio, R., and Rosén, P.: A paleoclimate record with tephrochronological age control for the last glacial-interglacial cycle from Lake Ohrid, Albania and Macedonia, J. Paleolimnol., 44, 295-310, doi:10.1007/s10933009-9404-x, 2010b.

Wagner, B., Reicherter, K., Daut, G., Wessels, M., Matzinger, A., Schwalb, A., Spirkovski, Z., and Sanxhaku, M.: The potential of Lake Ohrid for long-term palaeoenvironmental reconstructions, Palaeogeogr. Palaeoecol., 259, 341-356, 2008.

Wagner, B., Lotter, A. F., Nowaczyk, N., Reed, J. M., Schwalb, A., Sulpizio, R., Valsecchi, V., Wessels, M., and Zanchetta, G.: A 40,000-year record of environmental change from ancient Lake Ohrid (Albania and Macedonia), J. Paleolimnol., 41, 407-430, 2009.

Wagner, B., Vogel, H., Zanchetta, G., and Sulpizio, R.: Environmental changes on the Balkans recorded in the sediments from lakes Prespa and Ohrid, Biogeosciences Discuss., 7, 3365-3392, doi:10.5194/bgd-7-3365-2010, 2010.

Wilson, G. P., Reed, J. M., Lawson, I. T., Frogley, M. R., Preece, R. C., and Tzedakis, P. C.: Diatom response to the last glacialinterglacial transition in the Ioannina basin, northwest Greece: implications for Mediterranean palaeoclimate reconstruction, Quaternary Sci. Rev., 27, 428-440, 2008.

Wohlfarth, B., Veres, D., Ampel, L., Lacourse, T., Blaauw, M., Preusser, F., Andrieu-Ponel, V., Kéravis, D., Lallier-Vergès, E., Björck, S., Davies, S. M., de Beaulieu, J-L., Risberg, J., Mormes, A., Kasper, H. U., Possnert, G., Reille, M., Thouveny, N., and Zander, A.: Rapid ecosystem response to abrupt climate changes during the last glacial period in wester Europe, 60-16 ka, Geology, 36, 407-410, 2008. 